\title{
Public associations as means of formation of civil culture: search and solutions (1980-2002)
}

\author{
Dilovar Kalimullin ${ }^{1, *}$, and Gul'zirak Kalimullina ${ }^{1}$ \\ ${ }^{1}$ Kazan State Institute of Culture, 420059, 3 Orenburgskiy trakt, Kazan, Russia
}

\begin{abstract}
The present article focuses on the questions of civil culture in the Russian Federation. The main goal of this article is to state a problem of positioning in whole and attempt to provide a sociological interpretation of youth groups' positioning in the field of culture and policy in the modern Russian society, connected with three main strategies of political and public participation: conformism, nonconformism, and the alternative behavior directed on personal self-realization in the field of national culture outside the field politicians. The paper studies some aspects of civic culture formation in Russia in the context of the transition period. It argues a differentiated and hybrid nature of this type of culture and emphasizes the importance of civic consensus and solidarity. The article considers the features and analyzes the problems in the development of civil society in contemporary Russia, forming an interaction between institutions of the modern Russian state and the emerging civil society institutions. It is emphasized that in the Russian Federation the state plays the major role in their formation and causes the main tendencies of their further development, bringing both positive and negative consequences.
\end{abstract}

The research issue of public associations as a civil society structural element and as a civic culture development mean is highly topical today. It is well known that social and cultural updating priorities of the Russian society are the values of democracy, humanism, personal rights, and freedom. Based on a social pedagogical approach this refers to creation of an environment for the human personality full development as a social relationship actor, a statement of civic-mindedness as a mean of human and social development in the popular consciousness. Public societies have an important resource for citizenship foundation. The Russian "third sector" today are thousand organizations, initiating and implementing the publicly significant and useful projects; tens of thousands of volunteers gratuitously working for other people; millions of citizens - public association members. It is a field of professional self-realization on demand of innovative socio-cultural technology, providing employment of a significant number of citizens. Public associations today is a real power of civil society, this was evidenced through their social initiatives' dimension, crime and drug abuse prevention efforts, and the promotion of charity as a mean of personal self-realization and social value.

\footnotetext{
* Corresponding author: yearsgoby@yandex.ru
} 
The public associations' activities provide real conditions for citizens' influence on the legislative process, as well as on the process of political, economic, and social reforms. The competence of public associations to include a person in the system of public relations, to address socially significant issues, turn them into a school of political culture, as a form of civic participation, the vehicle providing an active position and the individual moral responsibility.

However, the public associations' capacity to provide the civic culture is not fully implemented. This is due to several factors: the "third sector" commercialization and the emasculation of the socio-cultural nature of this phenomenon; the traditional view on public associations as the leisure activity, which functions are limited to organization of the conditions for socialization and personal fulfillment; the absence of socio-cultural technologies and forms of public associations' interaction with other actors addressing social problems deficiency, which violates the third sector civil nature implementation; the crudity of theoretical issues related to contemporary forms of civic participation, establishing partnership with government, business, and various actors of social and cultural life. The research interest is focused on sociological, legal, economic, and organizational aspects of interaction between the "third sector" and business, non-profit organizations, and power structures. At the same time, the public associations' competencies in the formation of the individual civic culture is still not considered as the pedagogical research issue.

In recent years, the structure of the Russian socio-cultural space has significantly changed: its main components today are the state structures (1st sector), business (2nd sector), and the public associations - the voluntary, self-governing, non-profit societies based on the citizens' initiative, united on the basis of common interests for the common objectives' realization. Due to the democratization and the "third sector" entities' right to participate in the political life, as well as dramatic changes at the federal and regional level in social policy and the design of the third sector legal framework (in the 90s was legally enshrined the equality principle of all organizational and legal forms of social policy and the right of non-profit organizations existence was recognized), we can see a significant increase in the number of non-profit organizations.

The targeted audience of the projects being implemented by public associations today consists of children and teenagers, abandoned children, social orphans, and HIV-infected, drug addicts, alcoholics, homeless, refugees, migrants, senior citizens living alone, critically ill people. This fact indicates that the "third sector" in Russia is becoming a real power and supports the establishing civil society.

The public associations study has a long history. In the Soviet Union period, the sociocultural phenomenon peaked in the second half of 80 's - early 90 's. However, the sociocultural situation that changed in the early 90 -ies, theoretically and practically devalued the results of recent studies. The interest to the public associations' issue increased in the 90 's (which is supported by the number of publications, as well as dozens of organized interregional and regional scientific and practical conferences dedicated to current development issues of the "third sector" in Russia).

Present realities substantially modified the content and forms of public associations' activities, as well as the social institution's functions. Public associations, along with the socialization integration and self-identity functions are regarded as a civil culture formation resource. During the inter-sector cooperation process, public associations appear as a form of public dialogue and as a legislature feedback, they provide a greater transparency of public administration and increase the trust of citizens in state institutions, assume the social problems' resonator function, providing a non-violent and legal conflict resolution, thereby reducing the social tension and protest potential of the population (particularly, according to N. V. Bannikov). Creating the interpersonal solidarity primary form, based on 
shared interests, the non-profit organizations ensure the integrity of public organizations through the alignment of horizontal communication systems and the information channels. The public association participants, involving into the civilian relationships, gain opportunities for expression and development as socially responsible entities. In this context, study of the associations as part of civil society and the school of political culture in the new socio-cultural environment becomes highly important. This analysis aspect suggests a methodology and categorical device, allowing to consistently integrate and interpret the diverse and multi-level data in the framework of socio- pedagogical paradigm, as well as to identify that section of the problem, where the objective and subjective personal civil culture drivers appear as a socio-pedagogical conditions of the person selfrealization as well as its involvement in the active development of the social and cultural experience.

The theoretical basis of the research on public associations as means of formation of civil culture is based on the following layers of the socio-humanitarian knowledge: the problem of the amateurishness pedagogy and hobby clubs (studies of L. G. Bryleva, A. P. Markova, S. V. Perminova, E. I. Smirnova, S. B. Sinetskii, V. N. Sharonova), which consists of public associations and hobby clubs analysis as a specific form of amateur activity that satisfies the personal need for social and leisure activity extension, creating socialization and self-realization additional conditions; advocacy of amateur associations' formation principles and hobby clubs); sociology of public associations and movements, that considers the movement as the leading form of civic identity realization, the key theme is an analysis of the relationships between non-governmental non-profit organizations and state, the social partnership institution research, the creation of the conditions for the implementation of association's social resources, the involvement of non-profit organizations into the social programs' implementation (V. V. Kostyushev, O. N. Yanizkii): a survey of the trends, conditions, mechanisms and civil society issues in Russia The analysis methodology of the conditions and mechanisms of civil culture formation among public associations' participants was formed on the basis of: self-realization concept, which emphasizes the value of the individual principles; activity approach, which allows to understand personal formation patterns and explain the motives of civic participation, socialization theories, revealing patterns of social and cultural practices assimilation by individuals; research paradigms in the public movements' sociological framework (the movement as a result of the resources obilization, the process and result of the group of individuals' transformation into a community, as an individual socialization form).

Also, we consider civic culture as a basic element of civil society, the condition and the result of the third sector development. The characteristics of the different approaches, in which the civil society is considered from several points of view, as a public relationships' universal complex, opposing the state is given as well as the market democratic society specific for Western civilization form, the non-state social relations and social institutions area can be described as well as some type of communication between state and citizen.

Public organizations, which have a significant creative potential, determining the state of public consciousness, establishing, in the process of dialogue with authorities, the economic, political, social and cultural models of country development, play a special role in community, as an individual socialization form.

Also, the civic culture can be considered as a basic element of civil society, the condition and the result of the "third sector development." The characteristics of the different approaches, in which the civil society is considered from several points of view, as a public relationships' universal complex, opposing the state should be considered, as well as the market democratic society specific for the Western civilization form. 
The main feature of civil society is a high level of civic culture of the population, understood as a set of values, norms, and the modes of implementation of the personal life position. The basis of the value chain models is the idea of human rights and freedoms, the law authority, the principles of equal opportunities and the development conditions, mutual responsibility between citizens and state, a democratic framework, the balance of personal and social benefits. In practical terms, it is a pro-active attitude for the values approval, as individual and social life norms, as well as the individual potential realization in the public activities. One of the most important criteria of civil culture establishment, on a personal level, is a civic participation - the process, where citizens and public organizations interact with others (especially with state agencies and business) in order to solve urgent social problems. At the basement of civic participation is an individual proactive behavior, which has an inner determination and goes beyond social roles, presupposing a voluntary acceptance of the individual responsibility for the social problems' solution. In the subjective terms, the proactive civic behavior is a way to harmonize the personal and public areas, and a socialization and personal fulfillment form in the social sphere.

Public associations optimize cultural preserving and changing processes (of values, norms, ideals, lifestyles); create and play the possible modes of development that contributes to the cultural self-development; compensate and enhance the conditions for the personal individualization (self, acceptance, self-affirmation) and its socio-cultural integration (allowing the individual to identify with his community, to find a spiritual identity and solve his social and integration problems). In the sphere of social relations, associations perform organizational and regulatory functions, which gives a reason to consider them as a civil society institutions. This socio-cultural role of public associations considerably varies depending on the type of culture and the state model.

The public associations, as a space of civil culture establishment, could be classified according to the primary focus activity criteria. As a result, we have five groups associations addressing the problems of participants (i.e. their activity is directed into the group on its members); socially-oriented associations, which activity is directed outward; the public associations with environment orientation; associations with mixed type and the "third sector" infrastructure organization. The target audience of the first group are themselves, the association members. Their efforts are focused on finding the solutions for their own problems. It includes "self-help organization," unifying people with common problems (disabled people's organizations, feminist movement, associations of parents, etc.). Generally, they are focused on government assistance, as a source of resources; professional associations; "club-type organizations," comprising a diverse groups of selfdevelopment and communication, interest clubs, associations based on social status, interests; cultural and educational associations (in the field of art, physical, mental culture, communicative skills development et al.). The second group includes the associations addressed to current public problems and shaping norms and values of civic participation: charity associations (addressing the problems of the socially vulnerable categories of population). Their relationship with government is based on social partnership, they actively work with business, foreign foundations); complex associations whose mission is to promote the initiatives; foundations that provide financial support of the project in the framework of the chosen direction. In the group of "environment" associations the core are the historical-cultural and environmental organizations, based on the ideology of the social action concept. The fourth group (with mixed profile), where the concept of political influence is dominated, consists of: national-cultural organizations (Association of fellowcountrymen.); spiritual associations, socio-political organizations and clubs. The "infrastructure" organizations contribute to the "third sector" and participate in the civil society construction. They are multi-structural organizations, as well as centers, acting within the social movement (feminist, ecological) framework. 


\section{References}

1. N. V. Bannikova, Civil initiatives in the modern Russian city. Another field: sociological practices (Publishing House of the Middle Volga Research Center, Ulyanovsk, 2000)

2. G. M. Birzhenyuk, V. G. Derbin, A. S. Zapesotsky, Technology of information work of the trade union organization (St. Petersburg State University, St. Petersburg, 2009)

3. L. G. Bryleva, Cultural and educational work and communist education of working people (LGIC, Leningrad, 1977)

4. A. P. Markov, Amateur youth associations: states, trends, problems (LGIC, Leningrad, 1988)

5. V. Sharonova, Socio-pedagogical conditions of self-determination of personality in initiative youth associations (Dissertation) (St. Petersburg, 1991)

6. S. B. Sinetsky, Interaction of club institutions and initiative associations in the sphere of leisure (Doctoral Dissertation) (SPbGIK, St. Petersburg, 1991)

7. E. I. Smirnova, Club associations (Prosvescheniye, Moscow, 1977)

8. V. V. Kostyushev, Collection of works of the participants of the Ninth competition of young scientists and students (Norma, St. Petersburg, 2008)

9. I. S. Fatov, Business in Law: Economic-Law Journal, 1 (2008)

10. O. Yanitsky, Sociology of risk: key ideas (Mir Rossii, Moscow, 2003) 